\title{
Evaluating quality in professional experience partnerships for graduate teacher employability
}

\author{
Rebecca Walker ${ }^{1}$, Chad Morrison ${ }^{1}$ and lain Hay $^{2}$ \\ rebecca.m.walker@curtin.edu.au; chad.morrison@curtin.edu.au; iain.hay@mq.edu.au
}

Corresponding author: Chad Morrison

${ }^{1}$ Curtin University

${ }^{2}$ Macquarie University

\begin{abstract}
Over recent years, much has been said about the quality of Australian initial teacher education. Concerns about the preparation of pre-service teachers and the capacity of graduates to meet the demands of the classroom have re-emphasised professional experience as a fundamental component of high-quality teacher preparation. Simultaneously, this focus on professional experience has emphasised the importance of partnerships. Through policy, the formalisation of partnerships between initial teacher education providers and early learning centres and schools has been linked to quality assurance and auditing cycles which report on the ways that providers prepare graduates for teaching. The employability of suitably-prepared graduates and their early career traction are of particular interest to policy makers, regulators and teacher educators alike. As a result, establishing an evidence base for quality in professional experience partnerships is paramount. This paper reports on the evolution of a strategic partnerships model between one provider and its growing network of partner schools. This model has been developed through a comprehensive evaluation process, examining the nature of formal partnerships and the outcomes associated with them. Data presented here highlights outcomes identified by stakeholders as influential and enacted through formal partnerships. Analysis of data also emphasises ongoing priorities for partnership development, implementation and evaluation, collectively understood to be closely connected to graduate employability.
\end{abstract}

Keywords: initial teacher education, professional experience partnerships, graduate employability;

\section{Introduction}

There is a clear relationship between graduate employability and authentic work experiences during Higher Education programs (Mason, Williams, \& Cranmer, 2009). Within high-quality initial teacher education (ITE), professional experience programs provide work integrated learning opportunities that are critical for pre-service teacher development (Flores, 2018; Le Cornu, 2015; 2016). These understandings underpin and reflect the approach taken by one of Australia's largest Schools of Education to deliver ITE programs that adequately serve the needs of its teaching graduates and their school communities. The School offers ITE to preservice teachers across all Australian states and territories and a very high proportion of those graduates gain employment within their local communities. In order to understand the needs of its diverse pre-service teacher cohorts and their local school communities, and to incorporate these understandings into course design, partnership activity, course delivery and evaluation, the School of Education has embarked on a continuous cycle of data-driven review. Of specific focus within this ongoing cycle of review is the impact of its strategic 
approach to partnerships with schools and learning settings in order to deliver professional experience. This paper reports on evaluating quality of these partnerships and its relationship to graduate teacher employability.

\section{Context}

\section{Policy reform within Australian initial teacher education}

Australian ITE has experienced significant pressure to reform over recent years, with policy development heavily focused on graduate outcomes. This has seen considerable attention paid to the quality of graduating pre-service teachers and the associated performance of ITE providers preparing them (Australian Institute for Teaching and School Leadership (AITSL), 2015; Department of Education and Training (DET), 2014; Teacher Education Ministerial Advisory Group (TEMAG), 2014). The sustained discourse about ITE and the classroom readiness of graduates, captured in the media and reflected in the views of politicians and the broader public (Stokes, 2018), has often concentrated on a perceived deficit in the skills, knowledge and capacity of graduate teachers and has fuelled much debate (Ingvarson, 2016; Morgan \& Aspland, 2018).

Classroom readiness was a significant theme within the TEMAG (2014) Review of Australian ITE with many of its recommendations related specifically to professional experience within ITE. The Australian Government Response (DET, 2015) to TEMAG also emphasised a practice-focused approach to ITE underpinned by closer ties between ITE providers and schools. A pervasive theme within this response was a disconnection between ITE providers and the early learning centres, schools and colleges that partnered with them, contributing to a variability of experiences of pre-service teachers. This, in turn, was associated with graduate teachers' employability (2015). The justification for much of this critique was that increasing numbers of graduate teachers were unprepared for the realities of the classroom and that university-based teacher preparation programs operated in relative isolation from the profession, adopting an overly theorised approach. Subsequently, mechanisms for promoting partnerships between ITE providers and their colleagues in the profession were codified into accreditation of ITE programs (AITSL, 2015; 2016).

\section{Professional experience partnerships in initial teacher education}

The abovementioned policy environment influencing Australian ITE has generated a range of responses from ITE providers (Ledger \& Vidovich, 2018), just as it has occurred in other parts of the world (Yeigh \& Lynch, 2017). A policy push to relocate more teacher preparation in schools has contributed to a range of innovative responses to professional experience and ITE (Ledger \& Vidovich, 2018), however innovative practice in this arena is not confined to post-TEMAG (for example, see Lang, Neal, Karvouni, \& Chandler, 2015; Ure, 2010). Nevertheless, the push for greater collaboration between ITE providers and schools and the new accreditation requirements to formalise these partnerships (AITSL, 2015) has thrust professional experience partnerships back into the spotlight.

The importance of relationships between ITE providers and their networks of professional partners within early learning centres, schools and colleges is well understood within ITE (Le Cornu, 2016). Under productive conditions, these relationships underpin the productive preparation of pre-service teachers by linking their theoretical and practical components (Ingvarson et al., 2014) within professional learning communities capable of providing critical socialisation (Sutherland, Scanlon, \& Sperring, 2005). Within rigorous and effective ITE programs, these components also support the development of critical inquiry and reflective practice about the authentic experiences and roles of teachers (Le Cornu \& Ewing, 2008). Importantly, this locates pre-service teacher development within communities of teachers engaged in the discursive process of understanding themselves and their teaching lives through classroom engagement and participation (Cohen, 2010). 
University-based teacher educators involved in professional experience have long understood the value of the relational aspects of professional experience partnerships (Morrison \& Le Cornu, 2014), despite these relational matters remaining relatively unacknowledged in broader settings (Carter, 2014). The high cost of delivering professional experience through relationship maintenance, amongst other high-cost aspects, has served as a significant barrier (Ure et al., 2017). This includes the challenges associated with traditional approaches to supervising pre-service teachers and supporting their development (Yeigh \& Lynch, 2017). Furthermore, developing, implementing and maintaining partnerships is a complex task as partnerships are ever-changing (Darling-Hammond, 2010). Despite these challenges, partnerships present opportunities for early childhood centres, schools, colleges and ITE providers to work in beneficial, reciprocal ways (Cornelissen, McLellan, \& Schofield, 2017; Nielsen et al., 2017).

\section{Quality partnerships and graduate employability}

The importance of quality partnerships between ITE providers and their partner schools is understood to be imperative to quality preparation of pre-service teachers (Lynch \& Smith, 2012; Uusimaki, 2013) and how they navigate their early career phase. The challenge of disparate perspectives on preparing teachers, held by university-based teacher educators (teacher educators) and school-based teacher educators (supervising mentor teachers) (Bullough, 2005), is often acutely apparent within placement settings. This can then impact negatively on outcomes for pre-service teachers and continue to impact on them as graduate teachers in the early career phase (Cochran-Smith et al., 2015; Lynch \& Smith, 2012). While the contemporary call within policy and discourse is to locate more of this preparation in schools, strengthening ITE and supporting graduate employability comes from making explicit the links between ITE providers and their school-based colleagues (Ambrosetti, 2014; Rajuan, Beijaard, \& Verloop, 2008). Reliance upon traditionally-oriented models for interaction between teacher educators, supervising mentor teachers and pre-service teachers often exacerbates the challenges for pre-service teachers. Such an approach can markedly increase complexity and stifle pre-service teachers' agency and capacity (O'Grady, Guilfoyle, \& McGarr, 2018). These approaches also ignore the challenge and complexity that supervising mentor teachers encounter (Nielsen et al., 2017). Equally, maintaining differing philosophical approaches to teaching and learning and incompatible practices between ITE providers and their partner schools impacts negatively on graduate teachers' perceptions of their teaching roles and responsibilities (Cochran-Smith et al., 2015). Consequently, creating alignment of perspectives between stakeholders involved in preparing teachers for the profession, through strategic partnerships, is of immense benefit to all (Carter, 2014; Mason, 2013).

The intention to create more coherent and relevant ITE courses for pre-service teachers through strategic partnerships is supported and enacted by the boundary crossings that occur through explicit partnership arrangements (Sewell, Cody, Weir, \& Hansen, 2018). Strategic collaborations that elicit shared perspectives and priorities during teacher preparation have been shown to extend into the early career phase in ways that allow graduate teachers to also boundary cross into new professional spaces with sustainable professional capacities (Hammond \& McCallum, 2009; Ronfeldt, 2012). These partnerships between ITE providers and schools generate and advance their shared perspectives and priorities for teaching and learning that contribute to knowledgeable teaching graduates (Darling-Hammond, 2010). Moreover, emerging evidence is indicating that pre-service teachers who are supervised by instructionally effective supervising mentor teachers show enhanced capacity (Ronfeldt, Brockman, \& Campbell, 2018). Engagement between university-based teacher educators and supervising mentor teachers is providing evidence that this interaction makes the developmental needs of pre-service teachers more overt and more connected to the interactions that characterise partnership activities, as well as shifting the discourse about preparing teachers from a deficit view to one of shared concern and care (Grimmett, Forgasz, Williams, \& White, 2018). Importantly, this raising of perspectives, priorities and shared 
practice is not confined to formal relationships but is acknowledged as highly influential, permeating all aspects of how school communities engage outwardly with their communities (Cornelissen et al., 2017)

\section{Data-driven responses to ITE reform}

With the introduction of the Accreditation of Initial Teacher Education Programs in Australia: Standards and Procedures (AITSL, 2015), AITSL sought to create national consistency within Australian ITE. Specifically, the introduction of these program standards developed around Standard 1 and the ways that ITE providers demonstrated program impact. This emphasis included the ways that pre-service teachers were prepared throughout their ITE programs for graduate teaching and robust data reporting mechanisms that made this externally assessable. This external accountability represented a shift in emphasis within accreditation, from a focus on content to a focus on measurable, reliable performance outcomes.

An area of shared concern within the TEMAG Review (TEMAG, 2014) the Australian Government (DET, 2015) and the new accreditation requirements (AITSL, 2015) was the outcomes associated with professional experience. Standard 5 of the new requirements is devoted exclusively to this component of ITE. This standard focuses entirely on the conditions surrounding productive professional experience placements. In particular, this standard established the requirement for documentation of formal relationships and interactions between ITE providers and their partner schools, the roles of all those involved in delivering professional experience and processes for collecting data about this activity.

The School of Education reported on in this paper has been delivering ITE since 1975. For more than 40 years its ITE programs have undergone continual change as the evidence base relating to quality ITE has grown and evolved. Throughout this time, the School has continued to focus on evaluating its impact through formal reviews of its programs, including in the area of professional experience, to ensure employability of its graduate teachers.

During this contemporary period of rapid and considerable reform, underpinned by the need to generate and report on programmatic data, the School of Education was already active in generating data relating to its programs to inform future priorities, practice and challenges. Of particular interest to the School was the impact of a strategic partnerships program to strengthen practice in relation to professional experience. The priorities for ongoing data collection and analysis included the ways that the program was aligning the practice of all educators participating in professional experience activities; how the various roles of staff were understood, developed and strengthened to support the program's objectives and how this could be measured and assessed through valid and reliable data. This paper presents recently analysed data relating to its school partnerships program. This program and the data produced by ongoing monitoring and evaluation have been the catalyst for reform within professional experience within the School of Education. This evidence-based approach to partnership design and evaluation highlights some critical areas of discussion while also providing the impetus for later discussion of future data collection procedures.

\section{Project methodology}

\section{Background}

In 2011, sometime prior to the TEMAG review and changing accreditation requirements, the School of Education embarked on a partnerships program to strengthen its professional experience program. The central pillars of partnerships development included enhanced, reciprocal relationships between teacher educators and supervising mentor teachers that would support consistent and high-quality professional experience placements for pre-service teachers. This agenda was underpinned by intensive professional learning components delivered by designated partnership coordinators to develop school-based coaches to lead development within partner schools. At the end of 2013, a comprehensive first review into the 
impact and outcomes associated with this partnerships program was undertaken by the School of Education. The review analysed aggregated performance data from graduating cohorts of early childhood education and primary level pre-service teachers associated with the partnerships program schools and non-partnership schools. Survey data was also generated from these cohorts of pre-service teachers, alongside survey data from school principals and key staff, including school-based coaches. This data was generated to provide insights into:

- the extent to which the partnerships program contributed to the development of workplace-ready graduate teachers;

- the extent to which the partnerships program contributed to the development of schoolbased personnel working to prepare pre-service teachers through professional experience.

On the basis of this review, work was undertaken in 2016 by the School of Education to further enhance its formal partnership program with schools to strengthen professional experience.

\begin{abstract}
Aims
This project sought to evaluate the range of outcomes stemming from the development and initial implementation outcomes of a strategic partnerships model developed by an Australian ITE provider to engage its partners in high-quality initial teacher education. Specifically, it examined:
\end{abstract}

- How the partnership model influenced the nature and extent of formal and informal interactions between the School of Education and its partnerships schools;

- How various stakeholders associated with the School of Education and partnerships schools evaluate the importance and impact of the strategic partnerships model;

- The opportunities and challenges to sustaining the partnerships model;

- The impact of the partnerships model on interactions and outcomes for stakeholders across key partnerships.

The themes were pursued under the central research question: How and to what extent is the development and implementation of a strategic partnerships model enhancing the quality of initial teacher education programs within the School of Education and its partners? Under this theme, a key indicator of quality ITE is graduate teachers' employability and employment outcomes.

\title{
Data collection
}

Data presented here was collected as part of an ongoing strategic formal review of professional experience within one School of Education and across cohorts of pre-service teachers within two ITE undergraduate programs (Early Childhood Education; Primary). This data collection involved pre-service teachers, teacher educators and supervising mentor teachers associated with both non-partnerships (NP) and partnerships (P) school settings.

Human research ethics approval was sought and gained through the Deputy Vice Chancellor and the ethics committee of the institution of the ITE provider and from site principals from all participating $\mathrm{P}$ schools. Participation in the project was entirely voluntary and pre-service teachers and staff were not obliged to participate.

Surveys for this project were developed using the Australian Professional Standards for Teachers (AITSL, 2011). A total of five surveys were developed to cater for the cohorts of preservice teachers and staff targeted. Questions were designed to elicit the opinions and perspectives of participants using Likert scales with some brief text-based qualitative responses. The themes within all five surveys included: relevance of the practicum experience; perceptions of preparedness for the workforce; and, support for professional 
practice. While the spine of each survey was common, each of the five instruments were tailored to the specific roles of each group of participants.

Survey instruments were delivered via email accounts of identified cohorts. The survey platform utilised a commercial survey application. Data collection followed the completion of professional experience placement rounds and all survey instruments asked participants to report on their personal perspectives and experiences.

The focus of this data collection activity was specifically on pre-service teachers' perceptions of the alignment and coherence of their coursework and professional experience and how these enabled them to progress towards the Graduate Teacher Standards, both in P and NP settings. Additionally, the project sought to investigate whether graduate teachers who completed their final-year internship in a $\mathrm{P}$ school were considered to be well-prepared for teaching. Finally, the impact of partnerships and the associated professional learning offered to school-based staff was examined. The project therefore consisted of three phases:

1. A survey study of graduating primary and early childhood teachers;

2. A survey study of school personnel who took part in delivering the partnerships program in P schools;

3. A comparison of aggregated teaching grades awarded to pre-service teachers in $P$ and NP schools.

Data presented here relates to the phase 1 survey of a graduating cohort of pre-service teachers within the primary and early childhood undergraduate programs. All data was deidentified during initial analysis and aggregated at the level of NP and P schools.

A cohort size of 117 graduating pre-service teachers was identified for participation following completion of their final professional experience placement in either a $\mathrm{P}$ school (56 pre-service teachers) or a NP school (61 pre-service teachers). Hyperlinks to survey instruments were distributed and with multiple reminders sent to the cohort throughout the following month. A total of 51 pre-service teachers submitted responses to the survey (26 from NP schools, 25 from $P$ schools), giving a response rate of about $44 \%$ (45\% for P and $43 \%$ NP pre-service teachers). This response rate compares favourably with the estimated response rate of $26 \%$ to a similar Queensland survey (Ingvarson, Beavis, Danielson, Ellis, \& Elliott, 2005). Despite this favourable comparison, it must be acknowledged that these response rates must be considered inadequate. Generalisations about these findings cannot be made due to the small participant cohort (and descriptive quantitative analysis is only possible). Additionally, graduate teachers who voluntarily responded to this survey are likely to differ from the nonresponders in important ways (Johnson \& Owens, 2003).

\section{Findings}

Data presented here provides pre-service teachers' responses and perspectives about their experiences during their final professional experience placement (internship), immediately prior to graduating from their ITE program. Data from pre-service teachers who undertook professional experience placements in both $\mathrm{P}$ and NP schools are presented concurrently.

The following survey items sought to elicit pre-service teachers' perspectives about their inschool placement experiences, focussing on interactions that supported them to feel connected to their supervising mentor teachers and also to the collaborative culture of their school communities. 
Pre-service teachers across both NP and P cohorts reported consistently in relation to their supervising mentor teachers teaching them how to probe students' prior knowledge and to align their future teaching to it (Fig. 1). Over three-quarters of both cohorts (NP: $76.9 \%$; P: $82.6 \%$ ) reported strongly agreeing (NP: $26.9 \%$; P: 30.4) or agreeing (NP: $50 \%$; P: $52.2 \%$ ) with this item.

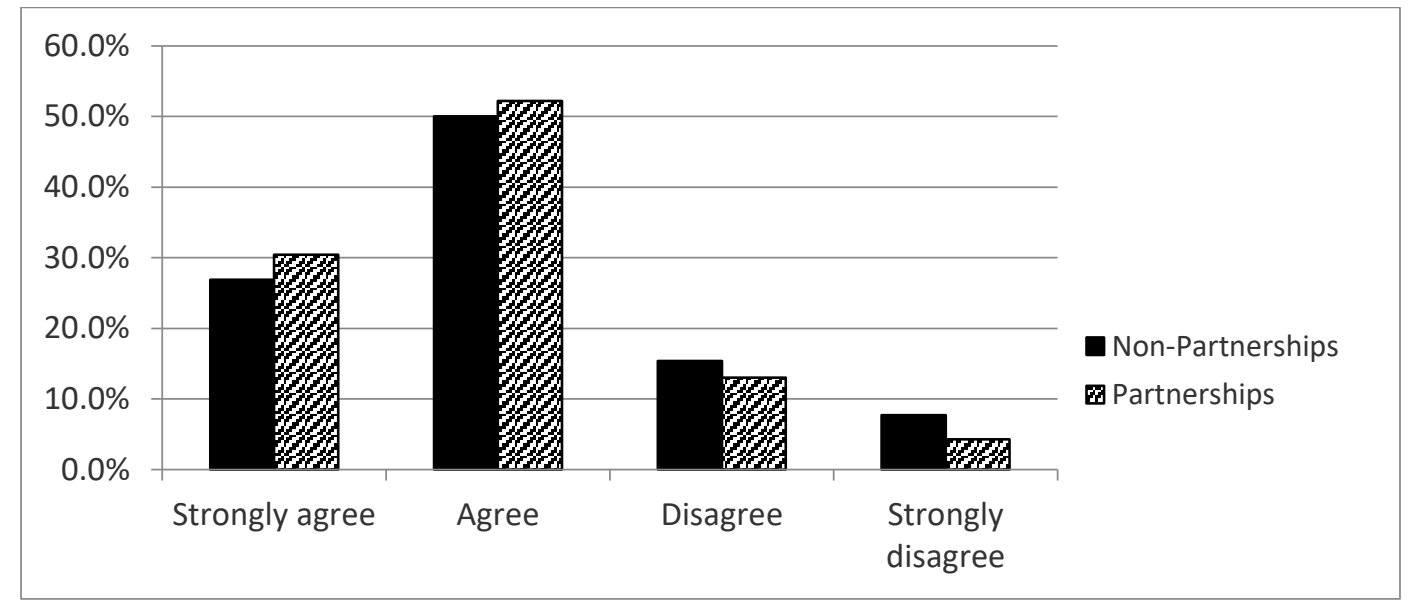

Figure 1: My Mentor Taught Me How to Probe Students' Prior Understandings and Present Content in a Way that Built on that Understanding

More than eight out of every ten respondents across both NP and P cohorts (NP: $84.6 \%, \mathrm{P}$ : $86.9 \%)$ reported that their mentor teacher helped them to develop content knowledge throughout their placement (Fig. 2).

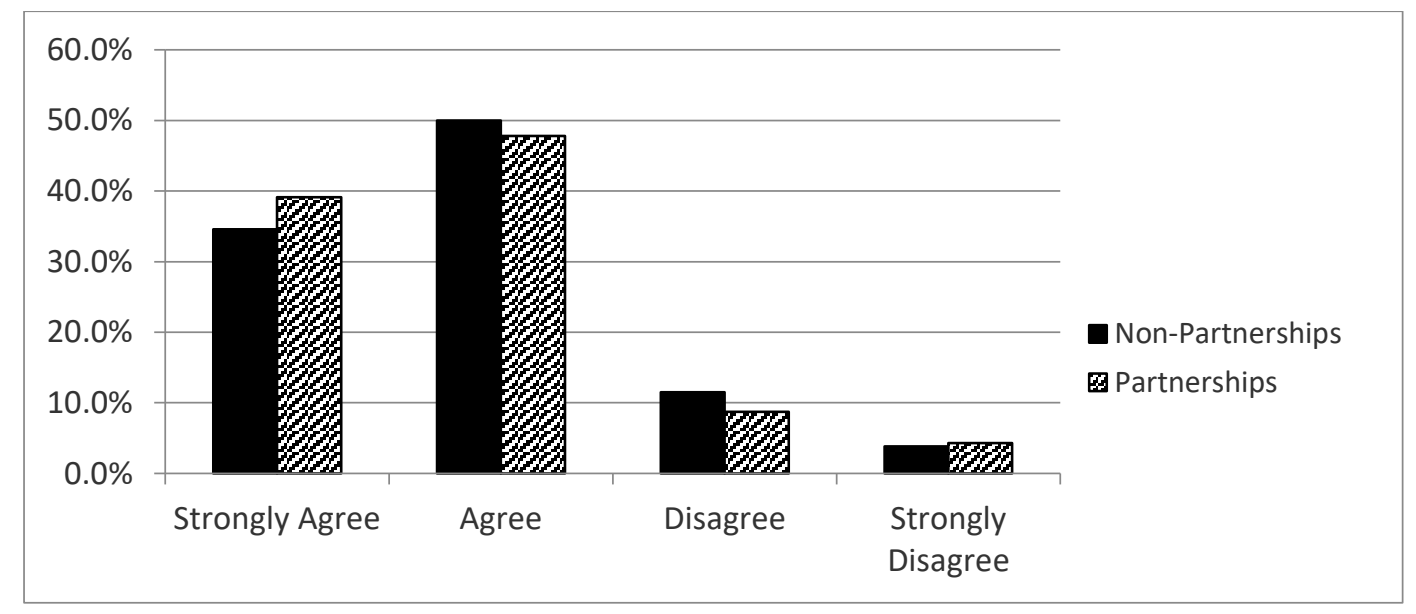

Figure 2: My Mentor Helped Me to Develop Content Knowledge of What I had to Teach 
Pre-service teachers undertaking placements in both NP and $\mathrm{P}$ schools responded comparably when reporting on opportunities to observe other teachers in their classrooms during their placements, other than their supervising mentor teachers (Fig. 3). One-third of both cohorts reported only occasionally having opportunities to observe other teachers (NP: 34.6\%; P: 33.3\%) and just under one-third reported rarely having these opportunities (NP: $30.8 \% ; 29.2 \%$ ). More than one-tenth of both cohorts reported never having these opportunities (NP: $11.5 \%$; P: $16.7 \%)$.

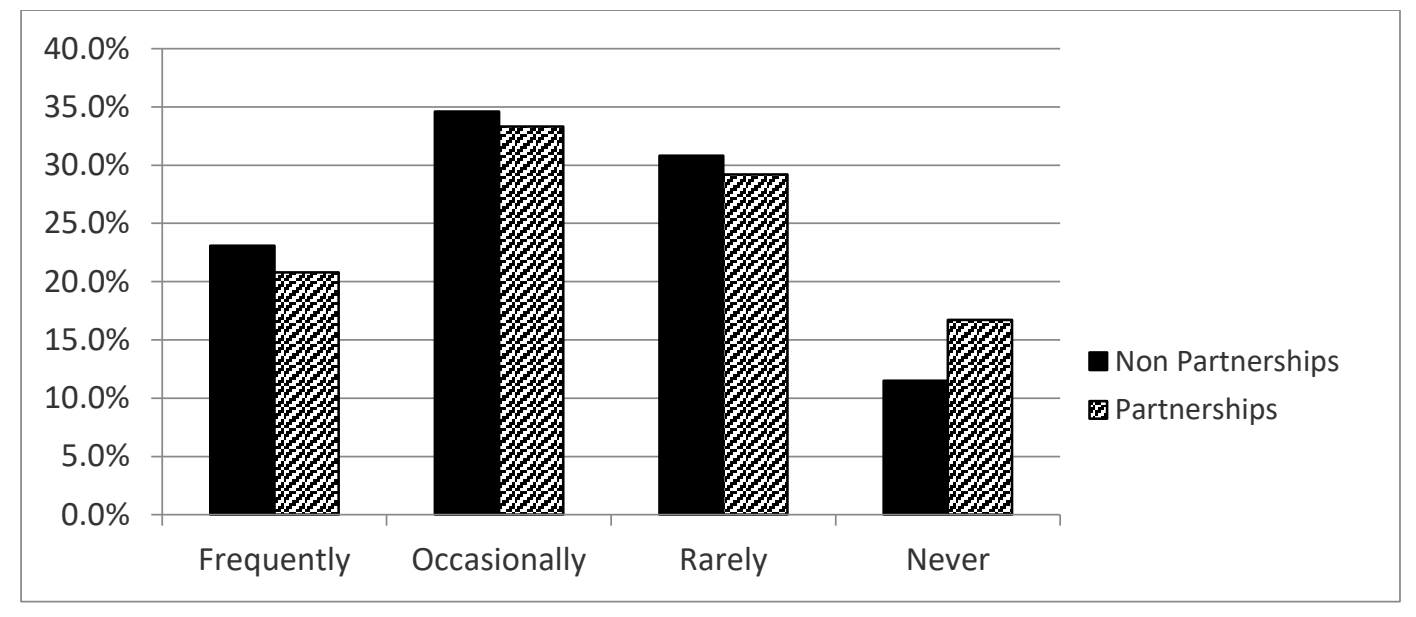

Figure 3: I had the Opportunity to Observe Other Teachers (Other than my Mentor)

Pre-service teachers placed at NP schools reported frequently joining meetings with other teachers for a range of purposes (NP: $84.6 \%$ ) more consistently than pre-service teachers placed within P schools (P: 66.7\%) (Fig. 4). Conversely, pre-service teachers at P schools reported higher response rates to Occasionally (NP: 11.5\%; P: 20.8\%) and Rarely (NP: 3.8\%; $\mathrm{P}: 12.5 \%)$ joining meetings with other teachers.

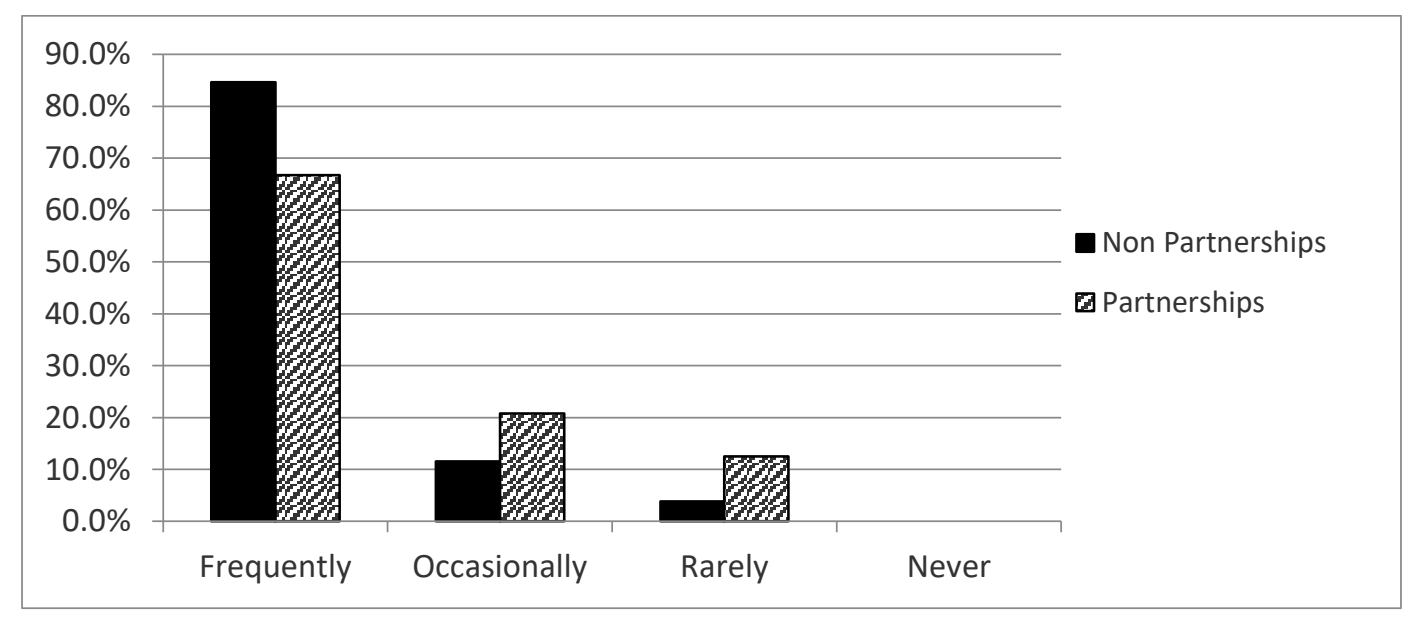

Figure 4: I Joined in Regular Meetings of Teachers. (e.g. Planning, Staff Meetings) 
Pre-service teachers working in NP schools more regularly reported frequently participating in tasks beyond their designated teaching roles (NP: $61.5 \%$ than those working in $\mathrm{P}$ settings (P: 41.7\%) (Fig. 5). Just under $30 \%$ of pre-service teachers placed in $\mathrm{P}$ schools reported rarely assisting in wider school activities (P: $29.2 \%$ ), in contrast to $7.7 \%$ in NP schools.

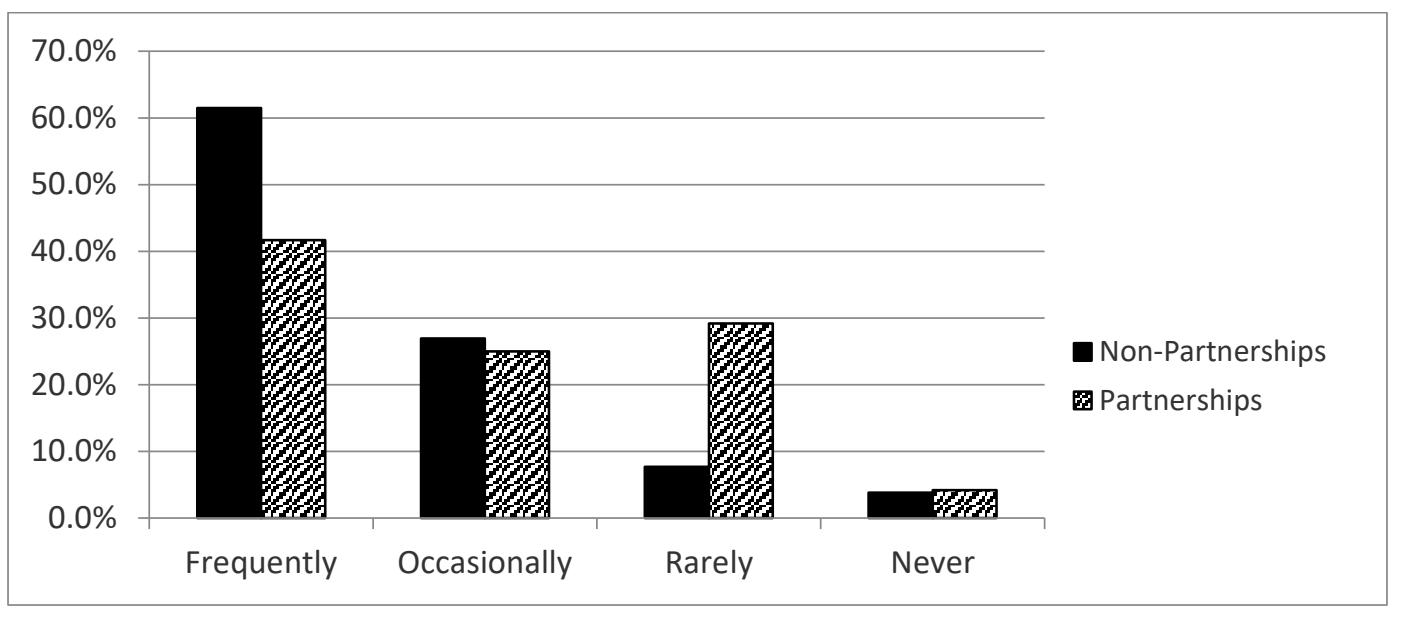

Figure 5: I Assisted with Wider School Activities. (e.g. Excursions, Camps, Sport, etc)

Patterns of interaction between pre-service teachers (Fig. 6) differed between NP and P schools, with pre-service teachers within NP settings reporting more frequent joint planning opportunities with their peers than those in P settings (NP: 11.5\%; P: 4.2\%). Opportunities for pre-service teachers to collaboratively plan with other preserve teachers were rare (NP: 26.9\%; P: $29.2 \%$ ) or never happened at all for over half of the NP cohort (NP: $53.8 \%$ ) and over one-third of the P cohort (P: $37.5 \%)$.

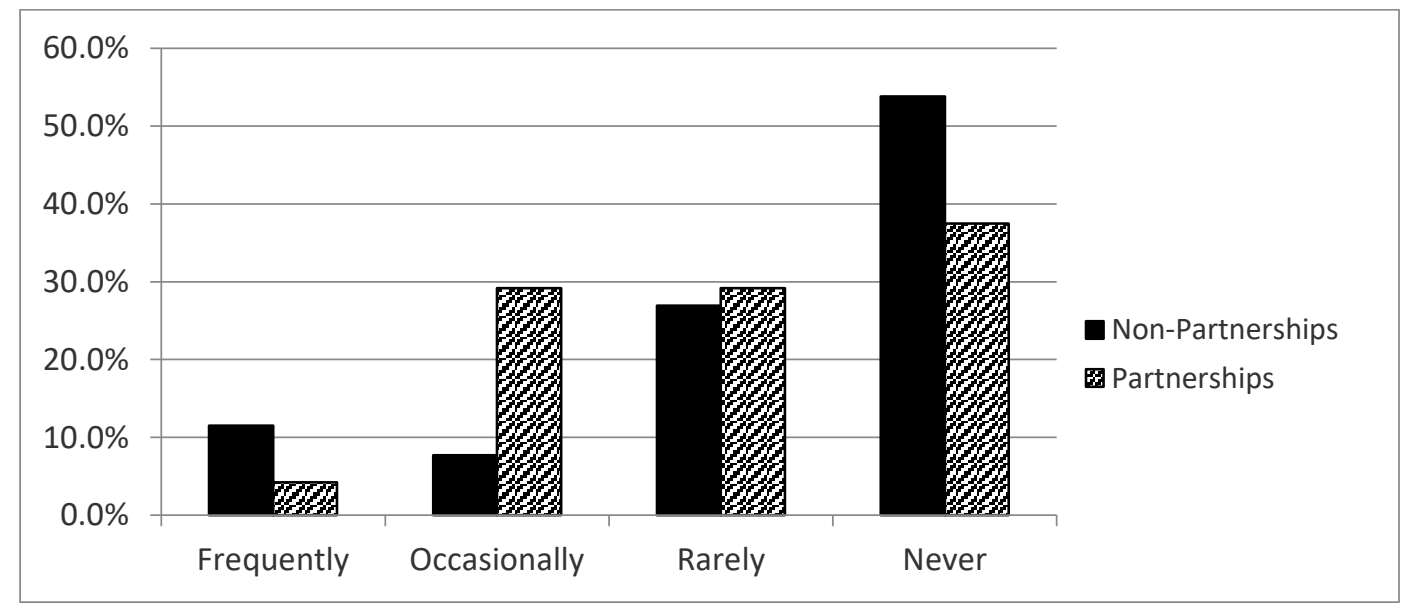

Figure 6: I Planned Lessons Jointly with Other Pre-service Teachers

The following data was drawn from survey items that explored pre-service teachers' perspectives about the expectations held of them during the placement. These items also explore how expectations held by supervising mentor teachers and university staff aligned or differed and how these expectations were made clear to the pre-service teachers. 
Approximately 9 out of every 10 pre-service teachers in both NP and P schools (NP: $89 \%$; P: $87.5 \%$ ) agreed they had a clear understanding of what was expected of them within their placement setting (Fig. 7).

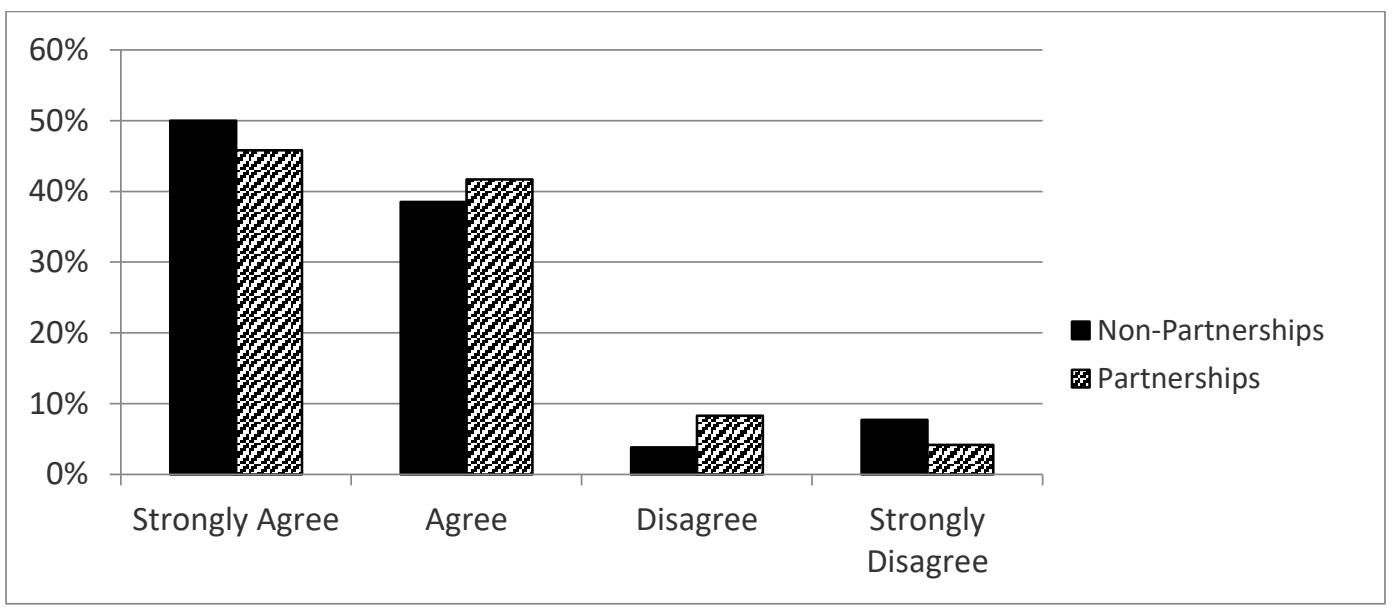

Figure 7: I had a Clear Understanding of What was Expected of Me at the School

Both cohorts of pre-service teachers reported high overall agreement (NP: 89\%; P: 82.6\%) that supervising mentor teachers were clear and explicit when reviewing their planning and teaching (Fig. 8). Over half of those placed in P schools strongly agreed (P: $56.5 \%$ ) while a further $26.1 \%$ agreed. Thirty-nine per cent of NP pre-service teachers strongly agreed while $50 \%$ agreed.

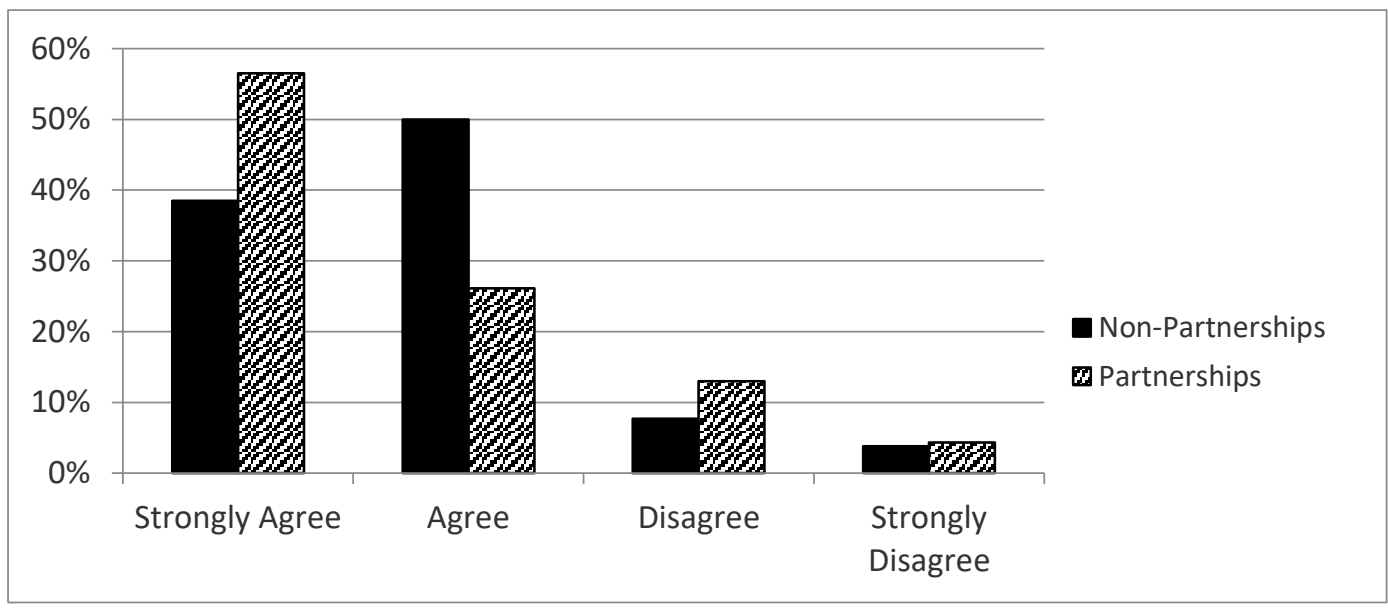

Figure 8: My Mentor was Clear and Explicit when Reviewing my Planning and Lessons with Me 
Equal rates of NP and P pre-service teachers (NP: 89\%; P: 88.9\%) agreed that their supervisor referred to clear and explicit standards when reviewing their work (Fig. 9).

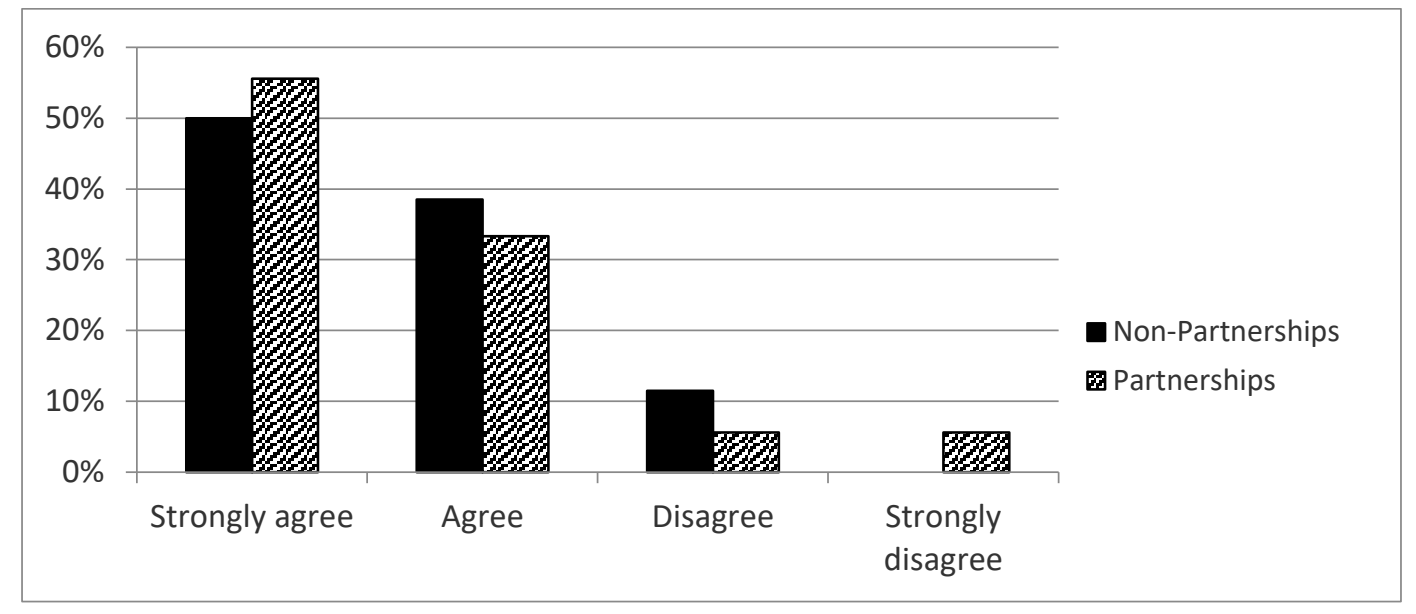

Figure 9: My Supervisor Referred to Explicit Standards when Reviewing my Lessons

Pre-service teachers located in $\mathrm{P}$ schools more frequently reported strong agreement (NP: $31 \% ; \mathrm{P}: 39.1 \%$ ) that their supervising mentor teacher had a clear idea about the ITE provider's expectations (Fig. 10). Equally, P pre-service teachers reported higher overall agreement that their mentor understood the placement requirements (NP: 77\%; P: 86.9\%).

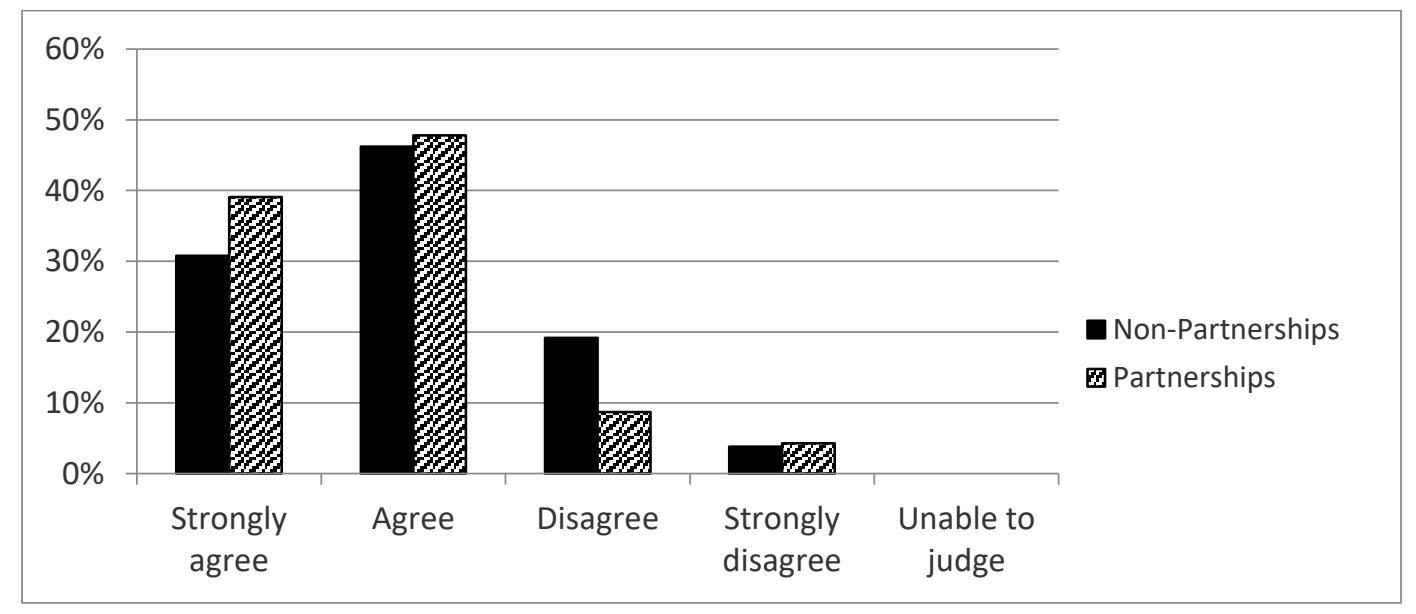

Figure 10: My Mentor had a Clear Idea of [ITE Provider's] Practicum Requirements 
Pre-service teachers at NP schools overwhelmingly agreed that their supervising mentor teacher and university lecturer(s) had similar views about good teaching (Fig. 11). In total, $96 \%$ of NP respondents agreed (NP: $73 \%$ ) or strongly agreed (P: $23 \%$ ) that there was alignment in beliefs within the team supporting them. In $\mathrm{P}$ schools, $86.9 \%$ of pre-service teachers also agreed (P: $56.5 \%$ ) or strongly agreed (P: $30.4 \%)$. Thirteen per cent of preservice teachers placed at $\mathrm{P}$ schools disagreed and a further $8.7 \%$ reported that they were unable to judge alignment of views between their supervising mentor teacher and university lecturers.

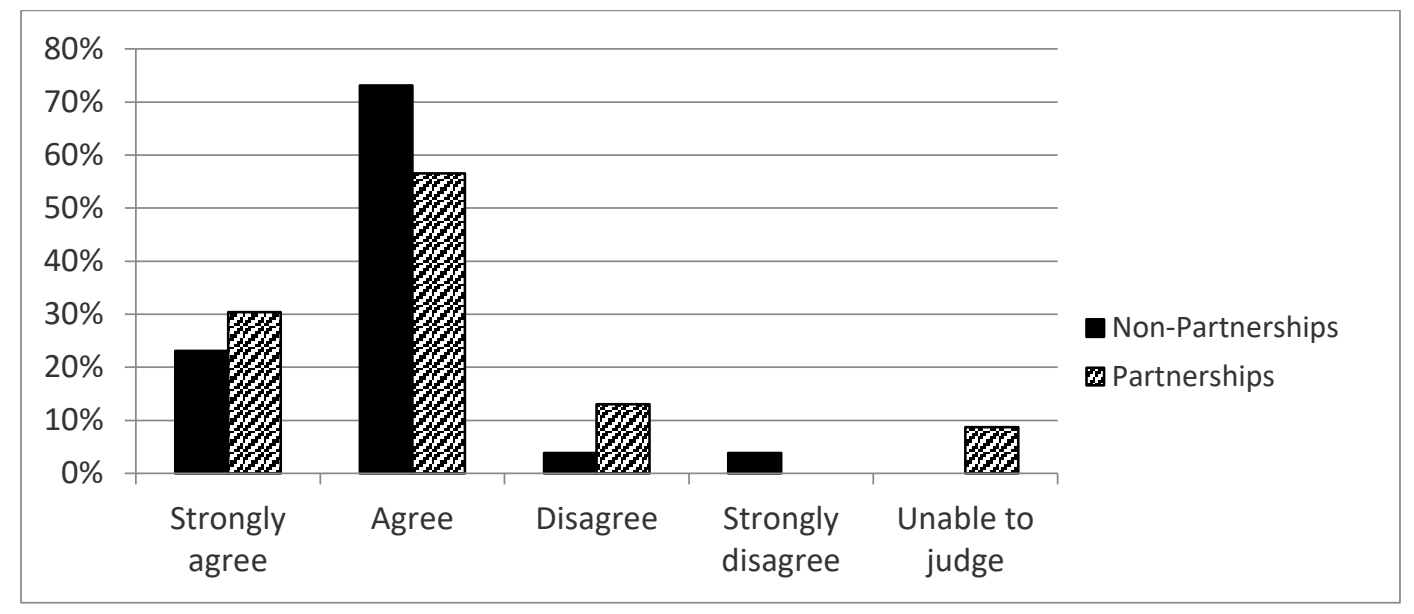

Figure 11: My Mentor and My University Lecturer(s) had Similar Views on Good Teaching Methods

Data presented here were drawn from survey items that sought to explore the value that preservice teachers attributed to the placement and the learning outcomes that were associated with it within the professional domains of teaching.

While slightly more pre-service teachers from NP than P schools (NP: 73.1\%; P $62.5 \%$ ) reported that they strongly agreed that their placement was a valuable part of their preparation (Fig. 12), pre-service teachers from both cohorts reported overall positive agreement to their final placement being of value (NP: 92.3\%; P: 95.8\%).

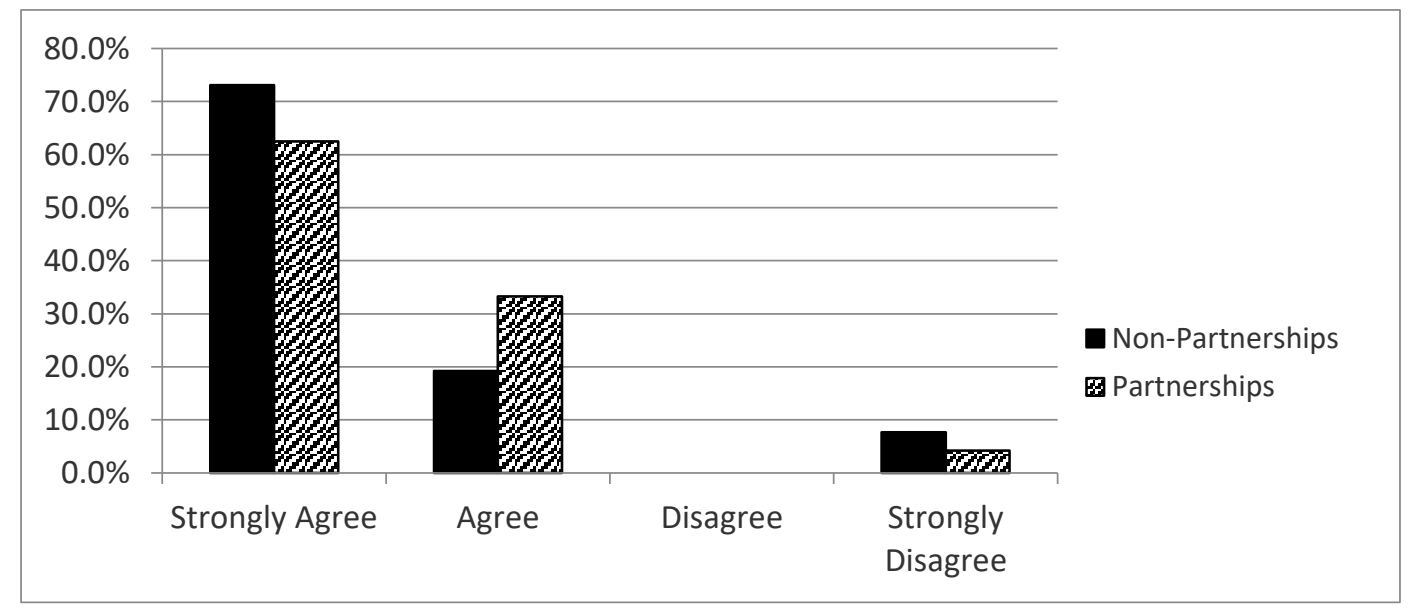

Figure 12: Overall My Final Practicum Experience was a Valuable Part of My Preparation in Becoming a Teacher 
Although responses to this item were overwhelmingly positive with over $90 \%$ agreement from both cohorts, pre-service teachers placed at NP schools reported that they strongly agreed that their placement was a valuable component of their preparation for teaching more frequently than those placed at $\mathrm{P}$ schools. Despite this, the follow-up qualitative responses from NP pre-service teachers that indicated a high level of variability in experience. This included statements like 'I had very little coaching from outside of my mentor teacher and only two supervised lessons' (NP respondent 1, line 1) and 'I had an awful experience... If I was asked to do so again I would change degrees' (NP respondent 7 , line 25). These responses were emotive and indicated the complexity experienced, as the following participant highlighted:

I felt as though it was an unfair assessment of my ability and did not reflect my journey... one bit... I did not have an opportunity to practice integrated programming, inquiry or any other alternatives of 'best practice'. I was judged on my ability to be a work sheet teacher...I was not invited to a single staff meeting - even when they were held in our classroom and I was there preparing and reflecting...It was the worst experience of my life (NP respondent 6, line 15).

Approximately $90 \%$ of respondents (NP: $88 \%$; P: 91.3\%) reported receiving feedback from their supervising mentor teacher which helped to improve their teaching (Fig. 13).

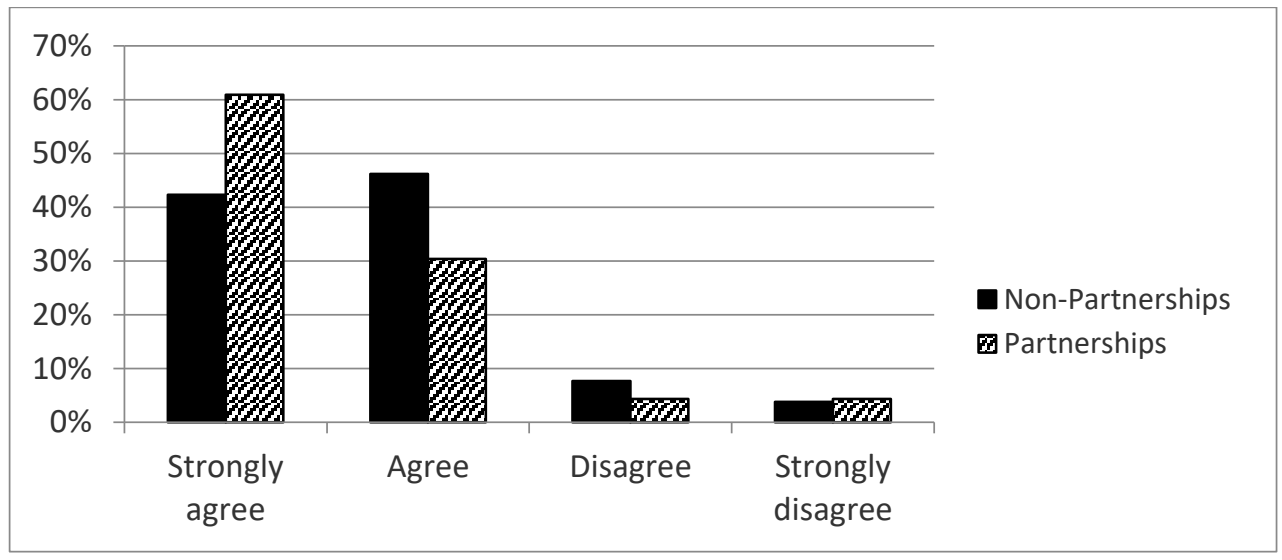

Figure 13: Feedback I Received from My Mentor Helped Me to Improve My Teaching

Pre-service teachers from NP reported slightly higher agreement responses than their $\mathrm{P}$ peers (NP: $88.4 \%$; $P: 82.6 \%$ ) in relation to their supervising mentor teacher helping them to develop a repertoire of effective teaching methods (Fig. 14).

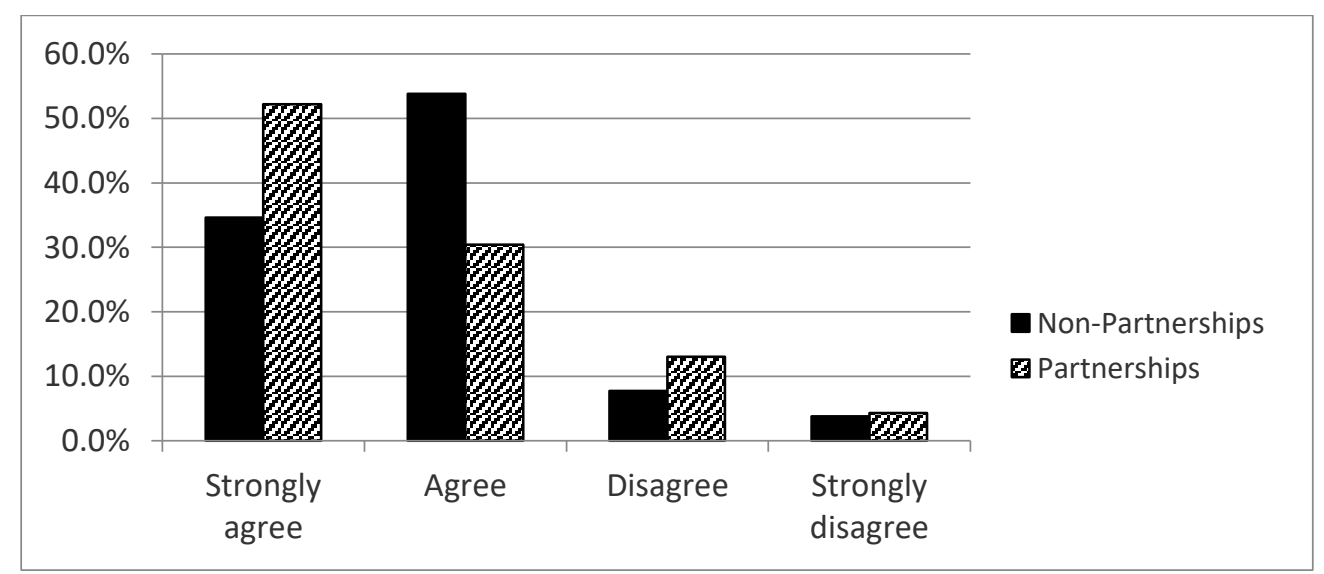

\section{Figure 14: My Mentor Helped Me to Develop My Repertoire of Effective Teaching Methods Specific to Content}


Over $90 \%$ of respondents from both cohorts (NP: 92.3\%; P: $91.3 \%$ ) reported their mentor teachers had taught them effective methods for managing student behaviour (Fig. 15).

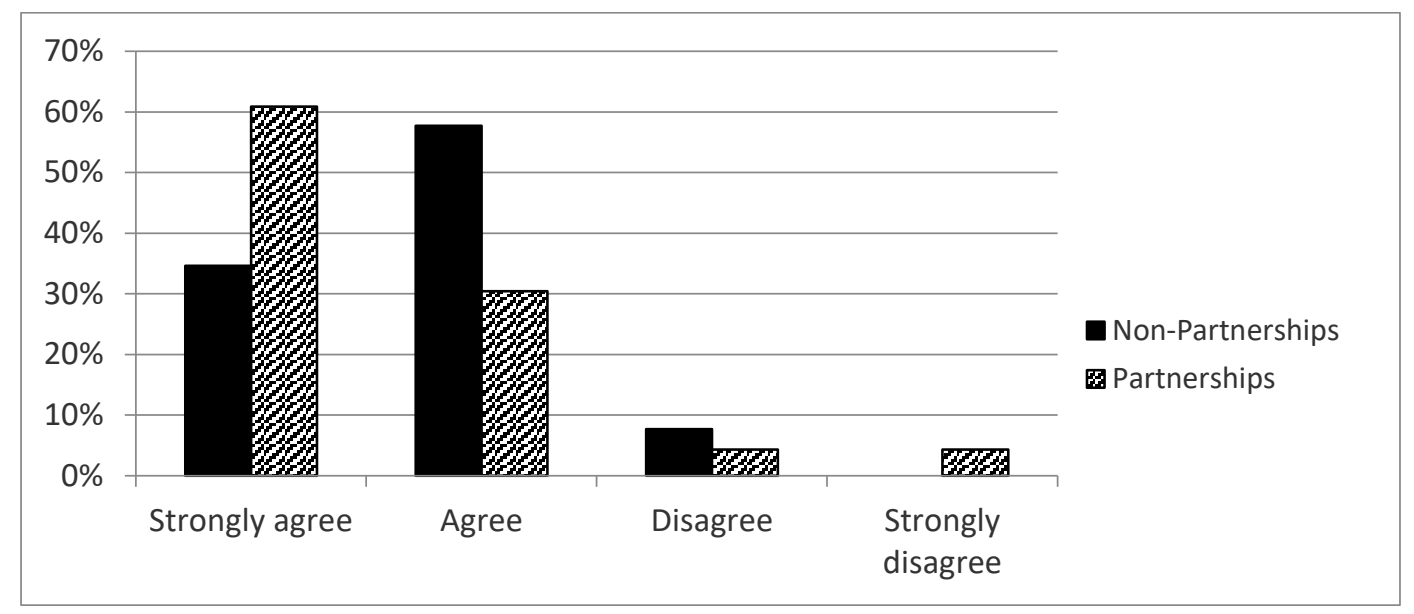

Figure 15: My Mentor Taught Me Effective Methods of Managing Behaviour

More than three-quarters of all respondents (NP: 77\%; P: 86.9\%) reported that their supervising mentor teacher had made clear links for them between theoretical components of their course and practical aspects of teaching during the placement (Fig. 16).

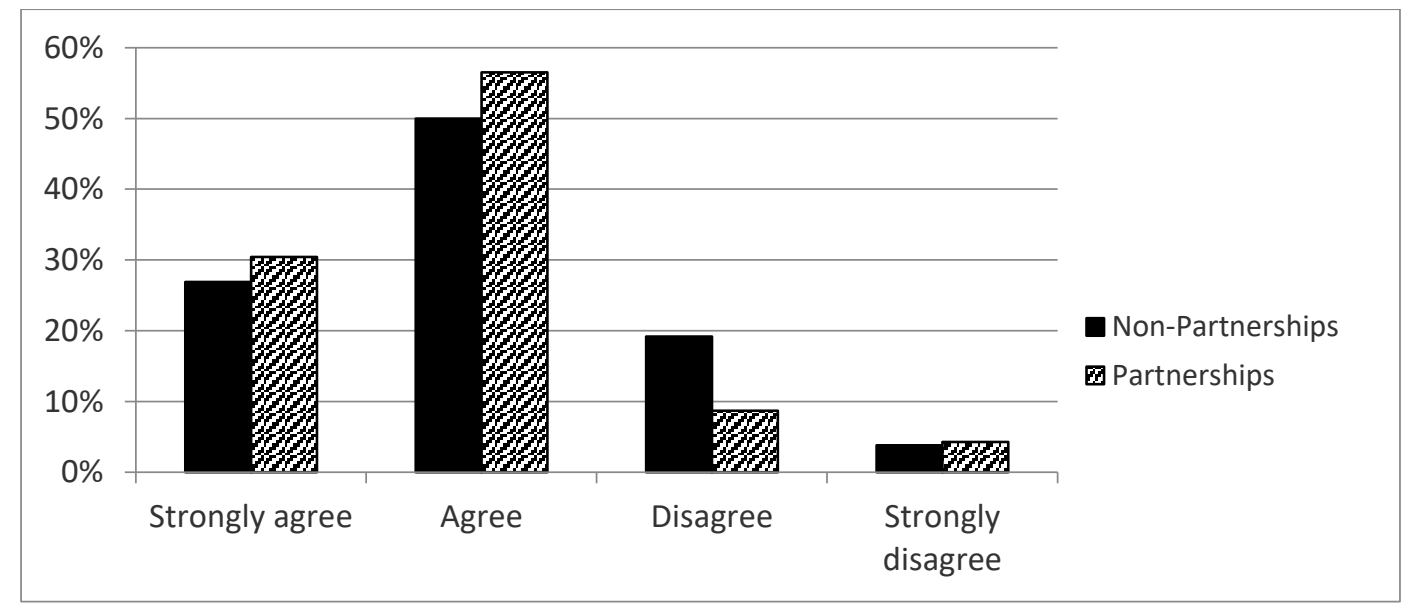

Figure 16: My Mentor Made Clear Links Between Theoretical and Practical Aspects of Teaching

Initial teacher education courses and professional experience components within those courses have received considerable resourcing and attention within the School of Education being reported on here. In particular, over the past five years the School has committed to a sustained focus of quality assurance through internal and external review cycles (Curtin University, 2014). This commitment to quality assurance and improvement within professional experience reflects the School of Education's awareness of the significant contributions that professional experience components make to graduate teachers' capacity and preparedness for the profession (DET, 2015).

Over recent years, the School of Education has invested heavily to focus its professional experience program around strategic partnerships with the profession, in recognition of the critical alignment between the two (Lynch \& Smith, 2012). Given the considerable resources directed towards strategic partnerships arrangements, and the basis on which this investment 
was made, pre-service teachers' responses within this study highlighted further work to be done.

Data reported here indicates that pre-service teachers' perspectives and responses to placements, in general, varied little between P and NP placement schools. This could be interpreted positively, as an indicator of consistency within supervising mentor teachers associated with the school. Given the great diversity of teaching contexts with which the School of Education works, this data does provide reasons to celebrate current interactions. However, the data also provides impetus for further analysis and future data collection.

Data collected from these two graduating cohorts of pre-service teachers emphasised that their perspectives differed only slightly across many measures of experience. Pre-service within NP and $\mathrm{P}$ schools consistently reported positively on most measures relating to overall value, contributions and outcomes associated with placement activities. Overall agreement within survey items were similar across NP and P and in many instances pre-service teachers placed in NP schools reported more favourably about their experiences, albeit slightly. The data also indicates potentially unintended consequences as a result of partnership arrangements, which require further consideration (Halliday, Asthana, \& Richardson, 2004).

\section{Pre-service teachers' perspectives about interaction during placement activities}

Figures 1-6 presented data relating to the shared responsibilities and complex undertakings of preparing graduate teachers for contemporary classrooms. The intersections between ITE providers and schools and the outcomes associated with these interactions are critical to graduate outcomes (Korthagen, 2001; Korthagen \& Kessels, 1999). Le Cornu (2015) argues that it is a critical time for Australian ITE to respond to the challenges that it is facing and emphasises the importance of collaboration between ITE providers and their partners to strengthen the ways that pre-service teachers meaningfully engage in teachers' work (Le Cornu, 2016).

Significantly, pre-service teachers within both cohorts consistently reported positive interactions within the placement settings. More than eight out of every ten respondents across both NP and P cohorts reported that their mentor teacher actively worked with them to develop content knowledge. They also consistently reported that their supervising mentor teachers worked with them to develop understandings about students (NP: 76.9\%; P: $82.6 \%$ ) and to manage student behaviour (NP: 92.3\%; P: 91.3\%). Equally, approximately $90 \%$ of all responding pre-service teachers reported receiving feedback from their supervising mentor teacher which helped to improve their teaching (NP: 88\%; P: 91.3\%) and that their mentors were instrumental in them developing effective teaching strategies (NP: 88.4\%; P: 82.6\%).

An unanticipated finding from the data was that pre-service teachers placed in $P$ settings appeared to be more confined to interactions with their supervising mentor teachers and to their specific teaching roles than those placed at NP settings. Pre-service teachers in $P$ settings reported slightly fewer opportunities to regularly observe other teachers. One-third of both cohorts reported only occasionally having opportunities to observe other teachers (NP: $34.6 \%$; P: 33.3\%) while nearly another third reported rarely having these opportunities (NP: $30.8 \% ; 29.2 \%$ ). Over $16 \%$ of the $\mathrm{P}$ cohort reported never having these opportunities. In addition, pre-service teachers placed at $P$ schools reported fewer opportunities than their NP peers to participate in meetings with other teachers (NP: $84.6 \% ; \mathrm{P}: 66.7 \%$ ). They also reported fewer opportunities for involvement in broader school activities than those placed in NP settings (NP: $61.5 \%$; P: 41.7\%) (Fig. 5). Approximately 30\% of pre-service teachers placed in $P$ schools reported rarely assisting in wider school activities (P: $29.2 \%$ ), compared to just $7.7 \%$ in NP schools.

This data indicates that pre-service teachers placed in $\mathrm{P}$ settings appeared to be more anchored to their primary teaching role and their interactions within the learning community were more limited than what was occurring in other settings. This pattern of interaction was also evident in the limited opportunities that pre-service teachers had to collaborate with other 
pre-service teachers during placement, however this was limited within both NP and P schools.

\section{Pre-service teachers' perspectives about expectations during placement activities}

Approximately nine out of 10 respondents in both NP and P schools (NP: $89 \%$; P: $87.5 \%$ ) agreed they had a clear understanding of the expectations held of them within their placement setting. They also responded that their mentor teachers were clear and explicit when working with them (NP: 89\%; P: 82.6\%) and applied explicit standards when reviewing their work (NP: 89\%; P: 88.9\%). Significantly, pre-service teachers placed in NP schools reported slightly higher agreement across these measures to pre-service teachers located in P schools. While these responses rates are positive and indicate clear communication of expectations to preservice teachers about how to navigate their school-based learning, the similarity of responses across cohorts seems to indicate that strategic investment in partnerships activities failed to translate into discernible outcomes for pre-service teachers.

Pre-service teachers consistently reported that their supervising teachers understood the requirements for the placement (NP: 77\%; P: 86.9\%). Pre-service teachers across both NP and $P$ settings also reported alignment between the views of mentor teachers and teacher educators about quality teaching (NP: 96\%; P: 86.9\%). Again, while these data highlight positive experiences for pre-service teachers and alignment between teacher educators and their school-based supervising mentor teachers, it indicates that more needs to be known about the quality and impact of partnership engagement.

\section{Pre-service teachers' perspectives about the value and outcomes of placement activities}

Participating pre-service teachers were at the point of graduation from their ITE courses when participating in this project. As discussed earlier, the low response rate from the graduating cohort limits what generalisations can be made of the data and analysis. Despite this, the perspectives shared highlight the overwhelmingly positive perspectives that these graduating teachers held about their placement settings and the outcomes associated with their final professional experience round. Respondents emphasised that they were supported to develop knowledge about their students' needs in relation to their learning and also about managing students' behaviours. Pre-service teachers reported being supported to develop curriculum knowledge and pedagogical skills. These indicators were provided by graduates just as they were making their transitions into the profession and so this data provides powerful perspectives on what they saw as productive.

It is within these areas of perceived value and outcomes associated with the final professional experience placement that the respondents who were placed in $\mathrm{P}$ schools started to illustrate the potential impact of strategic partnerships. Within the areas of increased knowledge of students, curriculum, pedagogy and practice, responses from pre-service teachers undertaking professional experience in $\mathrm{P}$ schools started to differ from their peers in NP schools. The partnership program presented areas of positive impact on pre-service teachers' preparation and in these domains $P$ pre-service teachers' responses rated higher in several measures over NP pre-service teachers. Despite this, the limitations of the cohort size meant that areas of further investigation and evaluation were identified for improvement and innovation within a context of a continual cycle of review.

\section{Conclusion}

The broad acknowledgement, at all levels of education (from school practitioners through to policy makers), of the crucial importance of professional experience has been the catalyst for a considerable reform agenda within Australian ITE. As a result, professional experience has been reinvigorated within accreditation processes and appears prominently in the ways that ITE providers document their engagement with the profession. This has included the 
formalisation of partnership arrangements between ITE providers and those centres and schools that host pre-service teacher placements and the agreements that structure, support and report on those interactions.

This project sought to evaluate the investment of one School of Education in its broader partnerships community and its commitment to education. The intention to strengthen professional experience to support the transition of graduate teachers into the profession is a central driver within this project. Collectively, a focus was to ensure that pre-service teachers effectively and productively navigate their professional experience placements. While it is acknowledged that this is important, these opportunities can also be critical to their capacity to negotiate the transition into the profession. By remaining focused on the quality of interactions and professional practice generated through strategic partnerships, it emphasised the need to further develop shared responsibilities and perspectives on preparing pre-service teachers who are able to survive, thrive and prosper throughout the early career phase. These important outcomes, realised through influential relationships between ITE providers and their professional partners, are well understood and have been influential in shaping the development of strategic partnerships to this point (Curtin University, 2014). These understandings are also influential in continuing to strengthen partnerships arrangements into the future. 


\section{References}

Ambrosetti, A. (2014). Are you ready to be a mentor? Preparing teachers for mentoring preservice teachers. Australian Journal of Teacher Education, 39(6), 30-42. DOI: http://dx.doi.org/10.14221/ajte.2014v39n6.2

Australian Institute for Teaching and School Leadership. (2011). Australian professional standards for teachers. Melbourne, Australia: AITSL.

Australian Institute for Teaching and School Leadership. (2015). Accreditation of initial teacher education programs in Australia: Standards and procedures. Melbourne, Australia: AITSL.

Australian Institute for Teaching and School Leadership. (2016). Guidelines for the accreditation of initial teacher education programs in Australia. Melbourne, Australia: AITSL.

Bullough, R. (2005). The quest for identity in teaching and teacher education. In G. F. Hoban (Ed.), The missing links in teacher education design: Developing a multi-linked conceptual framework (pp.237-258). Dordrecht, NL: Springer.

Carter, B. (2014). Situating beginning teachers in professional work through a regional community partnership. (Doctor of Philosophy), Victoria University, Melbourne, Australia.

Cochran-Smith, M., Villegas, A. M., Abrams, L., Chavez-Moreno, L., Mills, T., \& Stern, R. (2015). Critiquing teacher preparation research: An overview of the field, Part II. Journal of Teacher Education, 66(2), 109-121. DOI: 10.1177/0022487114558268

Cohen, J. L. (2010). Getting recognised: Teachers negotiating professional identities as learners through talk. Teaching and Teacher Education, 26(3), 473-481. DOI: 10.1016/j.tate.2009.06.005

Cornelissen, F., McLellan, R. W., \& Schofield, J. (2017). Fostering research engagement in partnership schools: Networking and value creation. Oxford Review of Education, 43(6), 695-717. DOI: 10.1080/03054985.2017.1316251

Curtin Univiersity, School of Education (2014). Curtin University practicum partnerships. Unpublished report. Perth, Australia: School of Education.

Darling-Hammond, L. (2010). Teacher education and the American future. Journal of Teacher Education, 61(1-2), 35-47. DOI: 10.1177/0022487109348024

Department of Education. (2014). Teacher Education Ministerial Advisory Group Issues Paper. http://www.studentsfirst.gov.au/teacher-education-ministerial-advisory-group: Australian Government.

Department of Education \& Training. (2015). Action now: Classroom ready teachers - Australian Government response. Canberra, Australia: Commonwealth of Australia.

Flores, M. A. (2018). Linking teaching and research in initial teacher education: Knowledge mobilisation and research-informed practice. Journal of Education for Teaching, 44(5), 621636. DOI: 10.1080/02607476.2018.1516351

Grimmett, H., Forgasz, R., Williams, J., \& White, S. (2018). Reimagining the role of mentor teachers in professional experience: Moving to I as fellow teacher educator. Asia-Pacific Journal of Teacher Education, 46(4), 340-353. DOI: 10.1080/1359866X.2018.1437391

Halliday, J., Asthana, S. N. M., \& Richardson, S. (2004). Evaluating partnership: The role of formal assessment tools. Evaluation, 10(3), 285-303. DOI: 10.1177/1356389004048279

Hammond, C., \& McCallum, F. (2009). Interdisciplinarity: Bridging the university and field of practice divide. Australian Journal of Teacher Education, 34(2), 50-63. DOI: http://dx.doi.org/10.14221/ajte.2009v34n2.5

Ingvarson, L. (2016). This is why our schools are in crisis. The Sydney Morning Herald. Retrieved from https://www.smh.com.au/opinion/this-is-why-our-schools-are-in-crisis20160817-gquaxl.html

Ingvarson, L., Beavis, A., Danielson, C., Ellis, L., \& Elliott, A. (2005). An evaluation of the Bachelor of Learning Management at Central Queensland University. Retrieved from https://research.acer.edu.au/teacher_education/5 
Ingvarson, L., Reid, K., Buckley, S., Kleinhenz, E., Masters, G., \& Rowley, G. (2014). Best practice teacher education programs and Australia's own programs. Canberra, Australia: Department of Education.

Johnson, T., \& Owens, L. (2003). Survey response reporting in the professional literature. Paper presented at the 58th Annual Meeting of the American Association for Public Opinion Research, Nashville, TN.

Korthagen, F. (2001). Linking practice and theory: The pedagogy of realistic teacher education. Mahwah, NJ: Lawrence Elbaum Associates.

Korthagen, F., \& Kessels, J. P. A. M. (1999). Linking theory and practice: Changing the pedagogy of teacher education. Educational Researcher, 28(4), 4-17. DOI: 10.3102/0013189x028004004

Lang, C., Neal, D., Karvouni, M., \& Chandler, D. (2015). An embedded professional paired placement model: 'I know I am not an expert, but I am at a point now where I could step into the classroom and be responsible for the learning'. Asia-Pacific Journal of Teacher Education, 43(4), 1-17. DOI: 10.1080/1359866X.2015.1060296

Le Cornu, R. (2015). Key components of effective professional experience in initial teacher education in Australia. Retrieved from Melbourne, VIC: Australian Institute of Teaching and School Leadership.

Le Cornu, R. (2016). Professional experience: Learning from the past to build the future. AsiaPacific Journal of Teacher Education, 44(1), 80-101. DOI: 10.1080/1359866X.2015.1102200

Le Cornu, R., \& Ewing, R. (2008). Reconceptualising professional experiences in pre-service teacher education: Reconstructing the past to embrace the future. Teaching and Teacher Education, 24(7), 1799-1812. DOI: 10.1016/j.tate.2008.02.008

Ledger, S., \& Vidovich, L. (2018). Australian teacher education policy in action: The case of preservice internships. Australian Journal of Teacher Education, 43(7), 11-29. DOI: http://dx.doi.org/10.14221/ajte.2018v43n7.2

Lynch, D., \& Smith, R. (2012). Teacher education partnerships: An Australian research-based perspective. Australian Journal of Teacher Education, 37(11). DOI: http://dx.doi.org/10.14221/ajte.2012v37n11.7

Mason, G., Williams, G., \& Cranmer, S. (2009). Employability skills initiatives in higher education: What effects do they have on graduate labour market outcomes? Education Economics, 17(1), 1-30. DOI: https://doi.org/10.1080/09645290802028315

Mason, K. O. (2013). Teacher involvement in pre-service teacher education. Teachers and Teaching: Theory and Practice, 19(5), 559-574. DOI: 10.1080/13540602.2013.827366

Morgan, A.-M., \& Aspland, T. (2018, September 8). Viewpoints: Should universities raise the ATAR required for entrance into teaching degrees? The Conversation. Retrieved from https://theconversation.com/viewpoints-should-universities-raise-the-atar-required-forentrance-into-teaching-degrees-102841

Morrison, C., \& Le Cornu, R. (2014). Teacher educators' beliefs about the purposes of professional experience. Paper presented at the 2014 Australian Teacher Education Association Conference, Sydney, Australia.

Nielsen, W., Mena, J., Clarke, A., O'Shea, S., Hoban, G., \& Collins, J. (2017). Australia's supervising teachers: Motivators and challenges to inform professional learning. Asia-Pacific Journal of Teacher Education, 45(4), 346-368. DOI: 10.1080/1359866X.2017.1304527

O'Grady, E., Guilfoyle, L., \& McGarr, O. (2018). 'Biting one's lip' and 'distancing': Exploring preservice teachers' strategies in dysfunctional professional relationships. Asia - Pacific Journal of Teacher Education, 46(4), 369-383. DOI: 10.1080/1359866X.2018.1469115

Rajuan, M., Beijaard, D., \& Verloop, N. (2008). What do student teachers learn? Perceptions of learning in mentoring relationships. The New Educator, 4(2), 133-151. DOI: 10.1080/15476880802014314

Ronfeldt, M. (2012). Where should student teachers learn to teach? Effects of field placement school characteristics on teacher retention and effectiveness. Educational Evaluation and Policy Analysis, 34(1), 3-26. DOI: 10.3102/0162373711420865

Ronfeldt, M., Brockman, S. L., \& Campbell, S. L. (2018). Does cooperating teachers' instructional effectiveness improve preservice teachers' future performance? Educational Researcher, 47(7), 405-418. DOI: 10.3102/0013189x18782906 
Sewell, A., Cody, T-L., Weir, K., \& Hansen, S. (2018). Innovations at the boundary: An exploratory case study of a New Zealand school-university partnership in initial teacher education. Asia-Pacific Journal of Teacher Education, 46(4), 321-339. DOI: 10.1080/1359866X.2017.1402294

Stokes, R. (2018, 20 September 2018). How universities lower teacher standards by focusing on profit. The Sydney Morning Herald.

Sutherland, L. M., Scanlon, L. A., \& Sperring, A. (2005). New directions in preparing professionals: Examining issues in engaging students in communities of practice through a school-university partnership. Teaching and Teacher Education: An International Journal of Research and Studies, 21(1), 79-92. DOI: 10.1016/j.tate.2004.11.007

Teacher Education Ministerial Advisory Group. (2014). Action now: Classroom ready teachers. Canberra, Australia: Department of Education and Training. Retrieved from http://www.studentsfirst.gov.au/teacher-educationministerial-advisory-group.

Ure, C. L. (2010). Reforming teacher education through a professionally applied study of teaching. Journal of Education for Teaching: International Research and Pedagogy, 36(4), 461-475. DOI: https://doi.org/10.1080/02607476.2010.513860

Ure, C. L., Hay, I., Ledger, S., Morrison, C., Sweeney, T., \& Szadura, A. (2017). Professional experience in initial teacher education: A review of current practices in Australian ITE. Retrieved from Canberra, Australia: Australian Council of Deans of Education.

Uusimaki, L. (2013). Empowering pre-service teacher supervisors' perspectives: A relationalcultural approach towards mentoring. Australian Journal of Teacher Education, 38(7), 4558. DOI: http://dx.doi.org/10.14221/ajte.2013v38n7.1

Yeigh, T., \& Lynch, D. (2017). Reforming initial teacher education: A call for innovation. Australian Journal of Teacher Education, 42(12), 112-127. DOI: http://dx.doi.org/10.14221/ajte.2017v42n12.7 